\title{
Rancang Bangun Prototipe Mobil Penjelajah Dengan Kendali Jarak Jauh Melalui Jaringan Wi-Fi Berbasis Antarmuka Web
}

\author{
Qisthi Al Hazmi Hidayatur-Rohman \\ Program Studi S1 Teknik Telekomunikasi \\ Institut Teknologi Telkom Purwokerto \\ qisthi@ittelkom-pwt.ac.id
}

\author{
Nur Sultan Salahuddin \\ Program Studi Sistem Komputer \\ Universitas Gunadarma \\ sultan@staff.gunadarma.ac.id
}

\begin{abstract}
Abstrak - Perkembangan teknologi berkembang sangat cepat, khususnya pada bidang robotika. Perkembangan teknologi telekomunikasi juga memiliki peran dalam perkembangan robotika, yaitu dalam hal teknologi komunikasinya. Mobil penjelajah merupakan aplikasi dari dunia robotika. Robot sudah banyak digunakan untuk banyak kasus, khususnya untuk penjelajahan suatu wilayah. Menjelajah suatu area yang tergolong berbahaya, seperti daerah kebakaran atau daerah yang memiliki tingkat kadar gas yang berbahaya cukup tinggi. Prototipe robot penjelajah ini bertujuan untuk membantu manusia dalam melakukan penjelajahan di area yang berbahaya tersebut. Pada robot penjelajah ini, digunakan beberapa perangkat yang dapat mendukung penjelajahan dengan jarak jauh, yaitu penggunaan Raspberry Pi sebagai komputer di robot ini, penggunaan wireless router yang berfungsi untuk komunikasi antara manusia dengan mobil penjelajah, sensor GPS yang bertujuan memberikan lokasi mobil, dan sensor kualitas udara yang bertujuan untuk mengetahui kadar gas pada area sekitar mobil. Halaman Web digunakan untuk antarmuka kendali mobil penjelajah.
\end{abstract}

Kata Kunci: Mikropengendali, Raspberry-Pi, Robot, Web, Wi-Fi.

\section{PENDAHULUAN}

Robotika sudah digunakan untuk banyak kebutuhan, dari industri besar sampai industri kecil, hingga sekarang juga sudah digunakan untuk kebutuhan lainnya. Dalam dunia penjelajahan, khususnya menjelajah daerah yang memiliki lingkungan ekstrim seperti daerah hutan yang terbakar atau daerah yang memiliki tingkat kadar gas yang berbahaya bagi manusia [1].

Perkembangan teknologi robotika sudah sangat cepat, khususnya untuk robot penjelajah. Robot penjelajah dikembangkan di berbagai bidang, baik itu untuk industri maupun untuk pendidikan. Perkembangan teknologi telekomunikasi juga mendukung perkembangan robot penjelajah [1]. Era saat ini, komunikasi tidak lagi selalu membutuhkan kabel untuk komunikasi, juga untuk kendali robot. Teknologi wireless membantu manusia dalam mengendalikan robot penjelajah pada jarak tertentu [2].

Penelitian ini bertujuan untuk merancang juga membangun sebuah robot penjelajah dengan menggunakan Raspberry Pi sebagai komputer yang terhubung dengan jaringan Wireless Fidelity (Wi-Fi) dengan antarmuka website untuk mengendalikan robot penjelajah tersebut. Beberapa perangkat pendukung diimplementasikan di dalam sistem robot tersebut. Seperti kamera yang digunakan untuk memberikan pemantauan area sekitar robot, sensor GPS untuk memberikan koordinat posisi robot saat menjelajah, dan sensor kualitas udara yang bertujuan untuk mengetahui kadar gas sekitar area robot.

\section{STUDI LITERATUR}

\section{A. Raspberry Pi}

Raspberry Pi merupakan komputer yang berukuran sebesar kartu kredit, yang memiliki fungsi selayaknya komputer yaitu dapat memproses sistem operasi, aplikasi, dan lain sebagainya [3]. Raspberry Pi dirilis di bawah lisensi Creative Commons. Akan tetapi, berbeda dengan komputer pada umumnya, Raspberry Pi memiliki General Purpose Input Output yang berfungsi selayaknya Arduino, yaitu untuk melaksanakan fungsi mikropengendali [3]. Raspberry Pi menggunakan mikroprosesor ARM yang memiliki daya rendah.

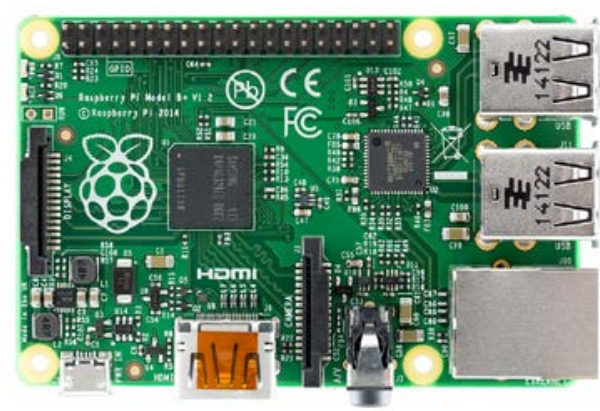

Gambar 1. Perangkat Raspberry Pi

Selayaknya komputer, Raspberry Pi dapat menjalankan fungsi-fungsi komputer, seperti mengolah data, membuka 
email, membuka internet, dan sebagainya. Selain fungsi tersebut, Raspberry Pi memiliki fungsi khusus yaitu dapat mengendalikan perangkat masukan dan keluaran selayaknya mikropengendali dengan menggunakan pin GPIO atau General Purpose Input Output. Pin GPIO digunakan untuk masukan dan keluaran digital, dan keduanya beroperasi pada 3.3V. Tidak seperti Arduino, Raspberry Pi tidak memiliki masukan analog, sehingga membutuhkan ADC atau Analogto-Digital Converter untuk mengonversi masukan analog menjadi bit digital [3].

\section{i. Komunikasi I2C}

Raspberry Pi menawarkan komunikasi I2C untuk komunikasi dengan perangkat peripheral lain dengan menggunakan pin GPIO 2 untuk SDA (Serial Data) dan pin GPIO 3 untuk SCL (Serial Clock). I2C kepanjangan dari InterIntegrated Circuit merupakan protokol serial untuk antarmuka dua-kabel untuk menghubungkan perangkat kecepatan rendah seperti mikropengendali, EEPROM, konverter A/D dan D/A, antarmuka I/O, dan perangkat lainnya di sistem tertanam. Kecepatan transfer datanya adalah antara 100 kbps, 400 kbps, dan 3.4 Mbps [3].

\section{ii. Komunikasi UART}

Selain I2C, Raspberry Pi memiliki komunikasi UART pada pin 14 GPIO untuk Tx dan pin 15 GPIO untuk Rx [3]. UART kepanjangan dari Universal Asynchronous Receiver/Transmitter adalah mikochip dengan pemrograman yang mengendalikan antar muka komputer. UART menggunakan transmisi serial asinkron. Asinkron berarti data yang ditransmisikan tanpa mendukung sinyal clock eksternal.

\section{B. Framework WebIOPi}

Framework WebIOPi adalah REST framework yang mengizinkan Raspberry Pi untuk mengendalikan GPIO melalui browser. Dituliskan menggunakan JavaScript untuk sisi klien dan Python untuk sisi server [3]. REST kepanjangan dari Representational State Transfer.

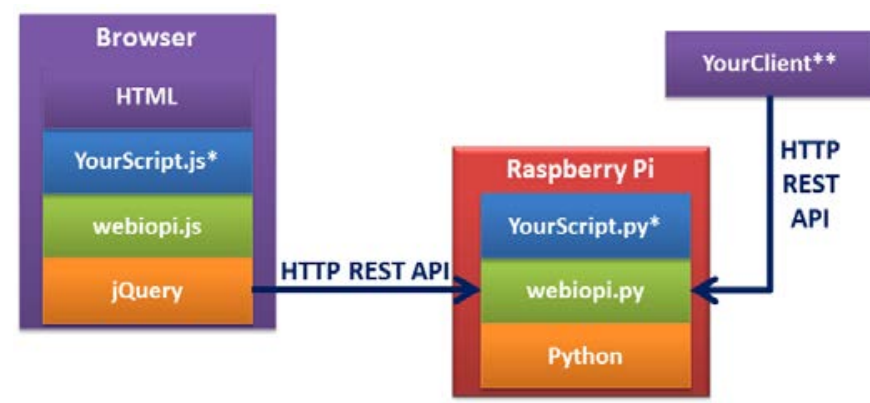

Gambar 2. Framework WebIOPi

\section{Wireless Fidelity}

Wireless Local Area Network (Wireless LAN) merupakan versi lain dari LAN, di mana jaringan komputer ini menggunakan frekuensi radio untuk jalur transmisi data. Wireless Fidelity atau Wi-Fi merupakan standar IEEE untuk 802.11x, dengan $\mathrm{x}$ adalah spesifikasi dari Wi-Fi. Jaringan WLAN pada umumnya menggunakan standar keluarga
802.11. Wi-Fi berjalan pada frekuensi $2.4 \mathrm{GHz}$ hingga $5 \mathrm{GHz}$, dengan jenis spesifikasi yaitu sebagai berikut [2]:

- 802.11a, transmisinya pada frekuensi $5 \mathrm{GHz}$ dengan menggunakan OFDM. Kecepatan datanya adalah 54 megabit per detik.

- 802.11b, transmisinya pada frekuensi $2.4 \mathrm{GHz}$, merupakan standar yang paling lambat pada perangkai wireless LAN. Kecepatan transmisi datanya adalah 11 megabit per detik.

- 802.11g, transmisinya pada frekuensi $2.4 \mathrm{GHz}$, dapat melakukan transmisi data sebesar 54 megabit per detik.

- 802.11n, transmisinya pada $2.4 \mathrm{GHz}$, merupakan standar paling cepat dengan kecepatan transmisi data maksimum 150 megabit per detik

D. GPS

GPS kepanjangan dari Global Positioning System merupakan utilitas milik US yang digunakan untuk layanan posisi, navigasi, dan waktu (PNT). Sistem ini terdiri atas tiga segmen, yaitu [4]:

- Segmen Antariksa, yang berisikan 24 satelit yang beroperasi pada konstelasi luar angkasa yang memberikan posisi dan waktu satelit GPS saat ini.

- Segmen Kendali, yang berisikan stasiun kendali dan pengawasan di dunia yang bertugas untuk mengelola serta merawat satelit untuk terus pada posisinya, serta melakukan pengaturan atas waktu satelit.

- Segmen pengguna, merupakan perangkat penerima GPS yang menerima sinyal dari satelit GPS lalu digunakan informasi tersebut untuk menghitung tiga dimensi posisi dan waktu pada pengguna.

Pada GPS dikenal istilah Trilateration, yaitu posisi satelit di mana satelit tersebut memberikan sinyal kepada segmen pengguna atau perangkat penerima GPS sesuai dengan posisi satelit pengirim dengan dua posisi satelit lain yang berkesinambungan [4]. Seperti contoh pada gambar berikut.

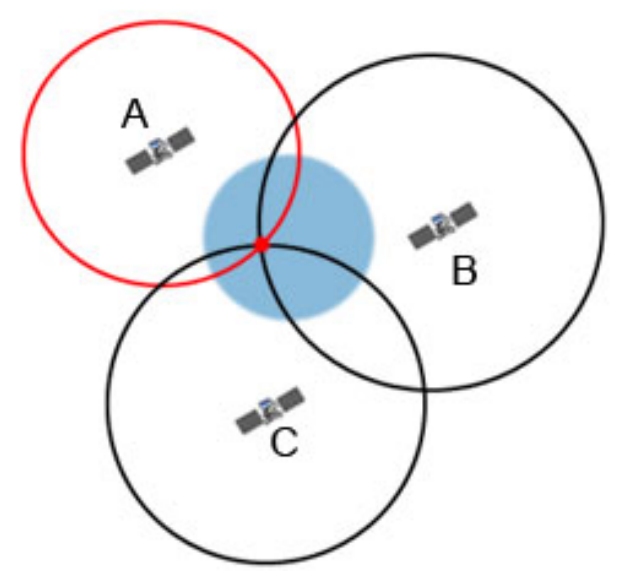

Gambar 3. Trilateration

\section{HASIL DAN PEMBAHASAN}

Pada bab ini akan membahas perancangan dari sisi hardware juga sistem, beserta hasil dari perancangan tersebut. 


\section{A. Diagram Blok Sistem}

Diagram blok di bawah berisikan proses sistem secara keseluruhan termasuk masukan dan keluaran. Secara garis besar, diagram blok sistem dapat dilihat pada gambar berikut.

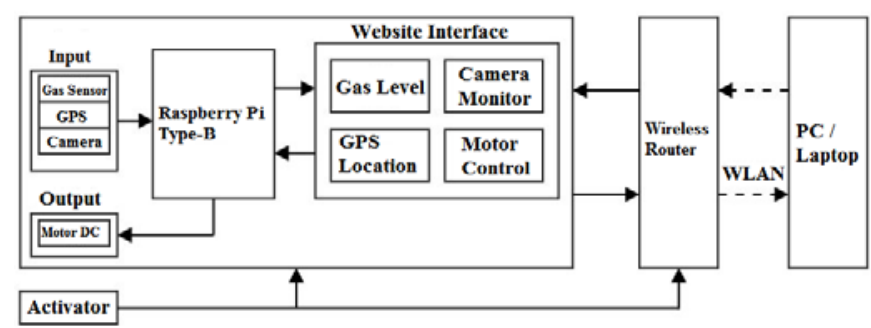

Gambar 4. Blok Diagram Sistem

Mobil penjelajah pada penulisan ini menggunakan Raspberry Pi tipe B yang bertujuan untuk memproses seluruh masukan dan keluaran. Pada perangkat penjelajah ini terdapat tiga perangkat masukan, yaitu sensor GPS, kamera, dan sensor kualitas udara, dan perangkat keluaran berupa motor DC sebagai penggerak mobil penjelajah. Raspberry Pi akan dihubungkan dengan wireless router yang berfungsi sebagai penghubung antara user dengan mobil penjelajah melalui jaringan Wi-Fi.

\section{B. Blok Wi-Fi}

Pada penulisan ini, Raspberry Pi dihubungkan ke Router TL MR-3020 untuk mengimplementasikan komunikasi Wi-Fi antara pengguna dengan perangkat mobil penjelajah. Router terhubung ke Raspberry Pi melalui port RJ45. Raspberry Pi harus diatur secara manual untuk dapat berkomunikasi melalui perangkat router tersebut dengan perintah [5]:

- \$ sudo nano /boot/cmdline.txt

- Lalu tambahkan alamat ip Raspberry Pi secara manual, $i p=192.168 .1 .1:: 192.168 .1 .254$

- Setelah menambahkan alamat IP pada Raspberry Pi, restart Raspberry Pi dengan perintah: \$ sudo reboot.

Setelah Raspberry Pi terhubung dengan router, laptop yang akan digunakan sebagai pengendali dapat dihubungkan dengan router melalui jaringan Wi-Fi. Setelah itu, laptop dapat melakukan pengecekan komunikasi antar laptop dengan Raspberry Pi dengan melakukan ping 192.168.1.1.

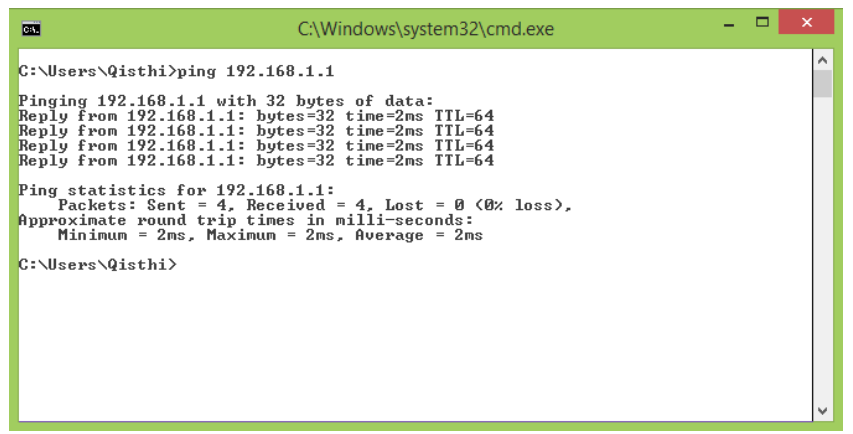

Gambar 5. Hasil Uji Coba Komunikasi

\section{Blok Kamera}

Raspberry Pi sudah mendukung driver kamera dengan menggunakan MJPG streamer [6]. MJPG streamer mengizinkan Raspberry Pi untuk menampilkan video dari kamera di antarmuka web. Untuk mengaktifkan MJPG streamer pada Raspberry Pi dapat melakukan instalasi $M J P G$ streamer dengan perintah berikut:

- \$ svn co https://svn.code.sf.net/p/mjpg-streamer/code/ mjpg-streamer

- \$cd mjpg-streamer

- \$ make

- \$ sudo make install

- Untuk mengetahui bahwa MJPG streamer sudah berhasil atau tidak dapat menggunakan perintah berikut: \$ sudo./mjpg_streamer-I “./input_uvc.so-d/dev/video0 -r $320 \times 240-f 25$ ” -o “./output_http.so -p 8080 -w www”

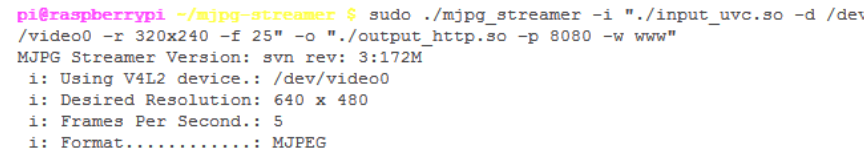

Gambar 6. Menjalankan MJPG Streamer

Port kamera yang digunakan adalah 8080. Port tersebut dapat digunakan di dalam kode program untuk antarmuka website. Berikut adalah hasil dari kamera pada port 8080.

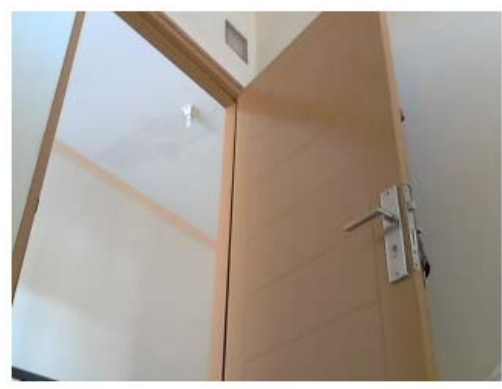

Gambar 7. Hasil dari Kamera

D. Blok GPS

GPS yang digunakan dalam penulisan ini adalah Parallax GPS Receiver Module. Raspberry Pi memiliki port untuk komunikasi serial (UART). Pada pin SIO pada GPS terhubung ke port Rx dan pin /RAW pada GPS terhubung ke port GND. Berikut adalah skematik rangkaian Raspberry Pi dan GPS.

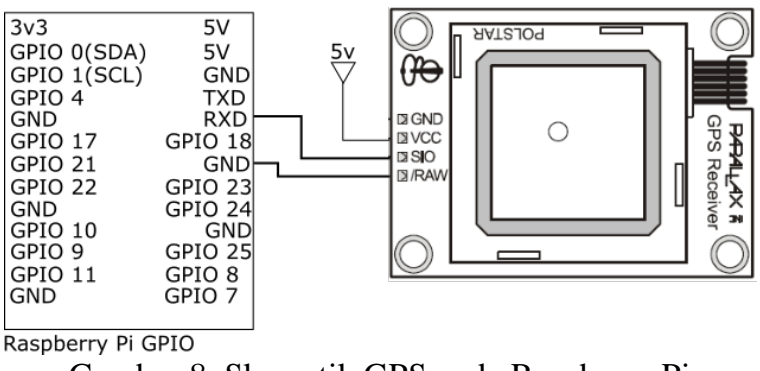

Gambar 8. Skematik GPS pada Raspberry Pi 
Komunikasi serial pada GPS tidak secara otomatis aktif, harus diaktifkan dengan manual dengan instruksi berikut:

- \$ sudo nano /boot/cmdline.txt, lalu hapus bit ini: console $=$ ttyAMA0,115200 kgdboc =ttyAMA0, 115200

- \$ sudo nano letc/inittab, lalu ubah T0:23:respawn:/sbin/getty -L ttyAMA0 115200 vt100 ke \#T0:23:respawn:/sbin/getty -L ttyAMA0 115200 vt100

- \$ sudo shutdown -r now

- \$ sudo apt-get install gpsd gpsd-clients python-gps

- \$ sudo stty -F /dev/ttyAMA0 4800

- \$ sudo gpsd /dev/ttyAMA0 -F/var/run/gpsd sock

- Uji coba GPS dengan perintah: cgps -s

\begin{tabular}{|c|c|c|c|c|c|c|c|c|}
\hline \\
\hline \multicolumn{8}{|c|}{ 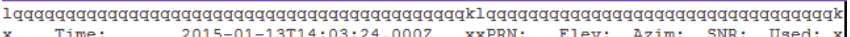 } & \\
\hline $\mathrm{x}$ & Latitude: & $6.361506 \mathrm{~S}$ & $\mathrm{xx}$ & 1 & 16 & 211 & 33 & $\mathrm{Y}$ \\
\hline & Longitude: & $.06 .850921 \mathrm{E}$ & $\mathrm{xx}$ & 3 & 34 & 257 & 42 & \\
\hline & Altitude: & $00.8 \mathrm{~m}$ & $\mathrm{xx}$ & 4 & 32 & 184 & 00 & $\mathrm{Y}$ \\
\hline$x$ & Speed: & $.0 \mathrm{kph}$ & $\mathrm{xx}$ & 8 & 18 & 024 & 00 & $\mathrm{Y}$ \\
\hline & Heading: & $.4 \mathrm{deg}$ (true) & $\mathrm{xx}$ & 11 & 31 & 200 & 42 & \\
\hline & Climb: & $.0 \mathrm{~m} / \mathrm{min}$ & $\mathrm{xx}$ & 14 & 20 & 138 & 28 & $\mathrm{~N}$ \\
\hline & Status: & D FIX $\left(\begin{array}{lll}62 & \text { secs }\end{array}\right)$ & $\mathrm{xx}$ & 16 & 20 & 000 & 24 & $\mathrm{~N}$ \\
\hline & Longitude Err: & $: \quad+/-21 \mathrm{~m}$ & $\mathrm{xx}$ & 19 & 78 & 181 & 41 & $\mathrm{~N}$ \\
\hline & Latitude Err: & $+/-13 \mathrm{~m}$ & $\mathrm{xx}$ & 20 & 10 & 282 & 25 & $\mathrm{~N}$ \\
\hline & Altitude Err: & $+/-99 \mathrm{~m}$ & $\mathrm{xx}$ & 23 & 25 & 331 & 00 & \\
\hline & Course Err: & $\mathrm{n} / \mathrm{a}$ & $\mathrm{xx}$ & 27 & 65 & 036 & 43 & $\mathrm{~N}$ \\
\hline & Speed Err: & $+/-152 \mathrm{kph}$ & $\mathrm{xx}$ & 31 & 16 & 069 & 00 & $\mathrm{~N}$ \\
\hline & Time offset: & 1.948 & $\mathrm{xx}$ & & & & & \\
\hline & Grid Square: & OI33kp & $\mathrm{xx}$ & & & & & \\
\hline
\end{tabular}

Gambar 9. Hasil dari Modul GPS menggunakan klien GPS sederhana

a) Uji coba GPS

Setelah GPS berhasil diambil datanya melalui perangkat Raspberry Pi, selanjutnya dapat dilihat melalui laptop yang masih terhubung satu jaringan dengan Raspberry Pi melalui jaringan Wi-Fi. Port GPS pada Raspberry Pi berada pada port 8000. Untuk melihat hasilnya menggunakan browser dapat dilakukan dengan menuliskan 192.168.1.1:8000 atau 192.168.1.1/gps di browser, dengan hasil seperti berikut.

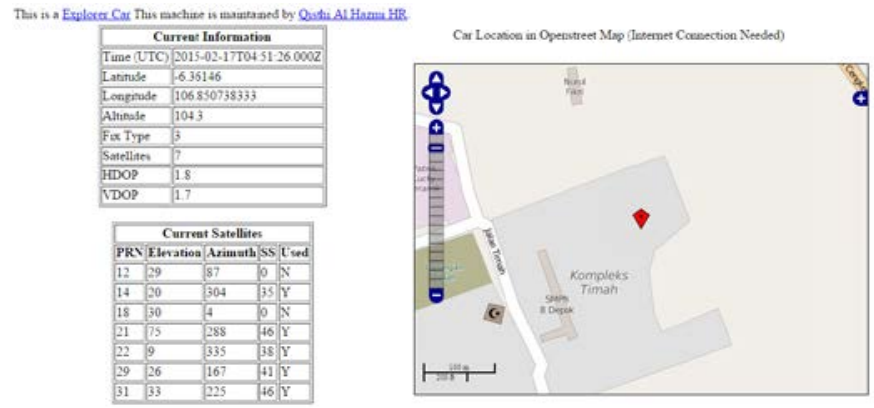

Gambar 10. Koordinat Posisi Perangkat dengan Peta

Peta pada browser menggunakan Open Street Map yang sudah terintegrasi secara otomatis. Untuk menampilkan peta OSM, perangkat pengguna (laptop) harus terhubung dengan internet. Pada Gambar 9 dan Gambar 10 menampilkan koordinat Latitude: 6.361476 S dan Longitude: 106.850823 E, atau dapat dituliskan dengan format: -6.361476, 106.850823. Untuk melakukan pembuktian posisi koordinat tersebut, dapat dimasukkan ke dalam Google Maps, seperti gambar berikut.

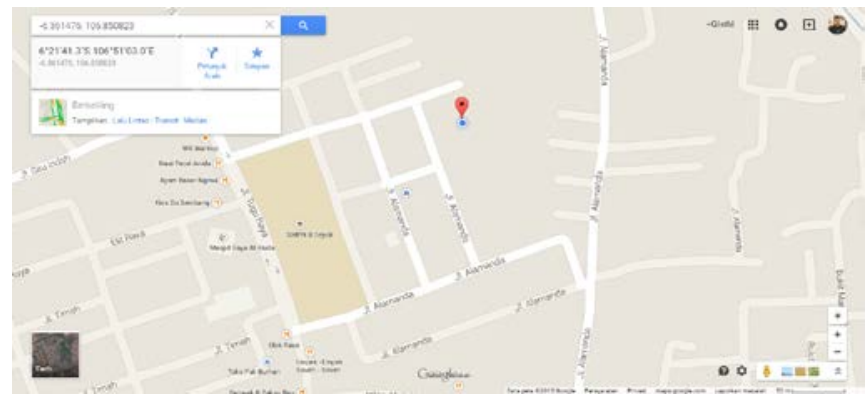

Gambar 11. Pembuktian Koordinat dari GPS Receiver pada Google Maps

E. Blok Sensor Kualitas Udara

Pada penulisan ini, sensor kualitas udara digunakan sebagai perangkat masukan untuk mengirim data dari sensor ke Raspberry Pi, lalu Raspberry Pi akan mengolah data tersebut dan dikonversikan menjadi nilai bentuk ppm. Sensor kualitas udara yang digunakan adalah modul DT Sense Air Quality dengan sensor MQ-135. Berikut skematik rancangannya.

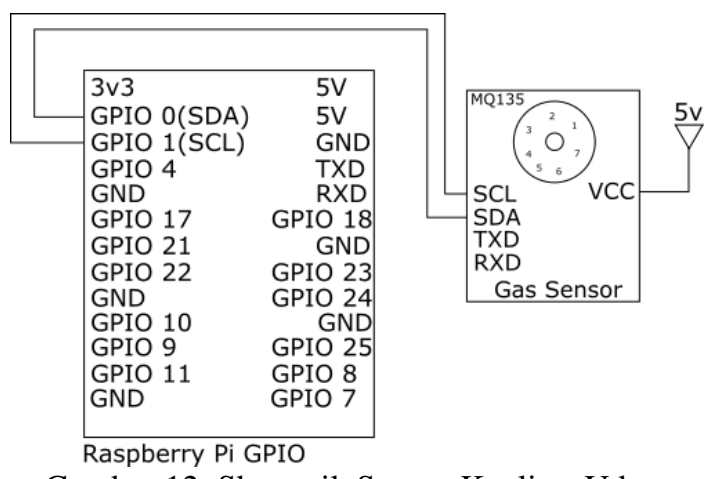

Gambar 12. Skematik Sensor Kualitas Udara

Sensor dihubungkan ke port I2C pada Raspberry Pi. Port I2C terdapat pada port 2 dan port 3 pada GPIO. Untuk menggunakan port I2C pada Raspberry $\mathrm{Pi}$, dapat dilakukan perintah berikut [7]:

- \$ sudo nano /etc/modproble.d/raspi-blaclist.conf lalu berikan tanda “\#” untuk blacklist i2c-bcm2708

- \$ sudo nano /etc/modules lalu tambahkan i2c-dev

- \$ sudo apt-get install i2c-tools python-smbuss

- \$ sudo adduser pi i2c

- Reboot Raspberry Pi

- \$ i2cdetect -y 1 untuk menguji perangkat lunak tersebut Keluaran dari Raspberry Pi terhadap sensor kualitas udara adalah berupa 10 bit data ADC (0 - 1023) sedangkan jarak deteksi sensor adalah 20 hingga 2000 ppm [7], lakukan linearisasi antara ADC dengan ppm pada sensor:

$$
\text { Gas Level }=\frac{(2000-20)}{1024}=1.943 p p m / A D C
$$

Sehingga diketahui bahwa untuk setiap nilai 1 ADC dari Raspberry Pi adalah 1.943 ppm. 
a) Uji coba Sensor Gas

Pada penelitian ini, konsentrasi gas dideteksi oleh sensor gas yang terimplementasi di Mobil Penjelajah. Dalam pengujian ini, sensor gas mendeteksi kandungan Karbondioksida $\left(\mathrm{CO}_{2}\right)$. Karbondioksida akan berbahaya jika kandungan karbondioksida di udara berada lebih dari 1000 ppm (parts per million) [8], itu berarti kondisi udara sekitar mobil penjelajah tidak bersih atau cukup berbahaya bagi manusia. Sumber karbondioksida yang digunakan pada penelitian ini adalah tumpukan kertas yang dibakar.

Pada uji coba sensor gas, diberikan 4 (empat) kondisi terhadap konsentrasi karbondioksida, berdasarkan referensi [8], yang dideteksi oleh sensor gas, yaitu:

1. Kondisi Udara Bersih: kurang dari 600 ppm,

2. Kondisi Udara Kurang Bersih (Waspada): 600 hingga 1000 ppm,

3. Kondisi Udara Tidak Bersih (Berbahaya): 1000 hingga 1500 ppm, dan

4. Kondisi Udara Sangat Tidak Bersih (Sangat Berbahaya): lebih dari 1500 ppm.

\section{GAS LEVEL}

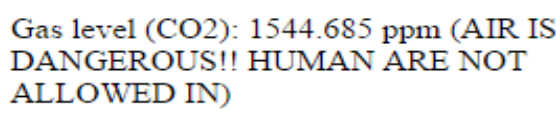

Gambar 13. Hasil Tampilan Gas Level dari Sensor Gas di Antarmuka Web

Gambar 13 merupakan tampilan dari nilai konsentrasi karbondioksida di dalam halaman web. Keterangan pada tampilan nilai dari sensor gas tersebut pun berbeda-beda tergantung dari nilai konsentrasi karbondioksida yang dideteksi oleh sensor gas.

Selanjutnya adalah uji coba jarak deteksi sensor gas terhadap sumber karbondioksida, yang mana adalah tumpukan kertas yang dibakar, dilakukan dua skenario kondisi, yakni kondisi luar ruangan dan kondisi dalam ruangan dengan jarak yang ditentukan (240 cm untuk kondisi luar ruangan dan $150 \mathrm{~cm}$ untuk dalam ruangan). Hasilnya ada pada tabel 1 dan tabel 2 .

Tabel 1. Pengukuran Jarak Deteksi Sensor Gas (Outdoor)

\begin{tabular}{ccc}
\hline Ujicoba & $\begin{array}{c}\text { Jarak ke } \\
\text { Sumber }(\mathbf{c m})\end{array}$ & $\begin{array}{c}\text { Konsentrasi } \\
\mathbf{C O}_{2}(\mathbf{p p m})\end{array}$ \\
\hline $\mathbf{1}$ & 240 & 576 \\
\hline $\mathbf{2}$ & 210 & 608 \\
\hline $\mathbf{3}$ & 180 & 610 \\
\hline $\mathbf{4}$ & 150 & 640 \\
\hline $\mathbf{5}$ & 120 & 676 \\
\hline $\mathbf{6}$ & 90 & 752 \\
\hline $\mathbf{7}$ & 60 & 817 \\
\hline $\mathbf{8}$ & 30 & 851 \\
\hline $\mathbf{9}$ & 15 & 981 \\
\hline $\mathbf{1 0}$ & $<15$ & $>1120$ \\
\hline
\end{tabular}

Tabel 2. Pengukuran Jarak Deteksi Sensor Gas (Indoor)

\begin{tabular}{ccc}
\hline Ujicoba & $\begin{array}{c}\text { Jarak ke } \\
\text { Sumber }(\mathbf{c m})\end{array}$ & $\begin{array}{c}\text { Konsentrasi } \\
\mathbf{C O}_{2}(\mathbf{p p m})\end{array}$ \\
\hline $\mathbf{1}$ & 150 & 1001 \\
\hline $\mathbf{2}$ & 120 & 1151 \\
\hline $\mathbf{3}$ & 90 & 1312 \\
\hline $\mathbf{4}$ & 60 & 1421 \\
\hline $\mathbf{5}$ & 30 & 1621 \\
\hline $\mathbf{6}$ & 15 & 1771 \\
\hline $\mathbf{7}$ & $<15$ & $>1800$ \\
\hline
\end{tabular}

\section{F. Antarmuka Web}

Antarmuka web pada penulisan ini digunakan untuk melakukan kendali penggerak motor DC pada robot penjelajah, juga untuk melakukan pengawasan terhadap kamera, indikator gas, dan posisi robot yang diberikan dari sensor GPS. Untuk mengimplementasikan antarmuka web pada Raspberry Pi dapat menggunakan aplikasi WebIOPi pada Raspberry Pi. WebIOPi berfungsi untuk mengendalikan GPIO pada Raspberry Pi. Berikut perintah untuk mengaktifkan WebIOPi:

- \$wget http://sourceforge.net/projects/webiopi/files/WebIOPi0.7.0.tar.gz

- \$ tar xvzf WebIOPi-0.7.0.tar.gz

- $\$$ cd WebIOPi-0.7.0

- $\$$ sudo./setup.sh

- Setelah melakukan instalasi, lakukan debug WebIOPi dengan perintah: \$ sudo webiopi -d -c /etc/webiopi/config
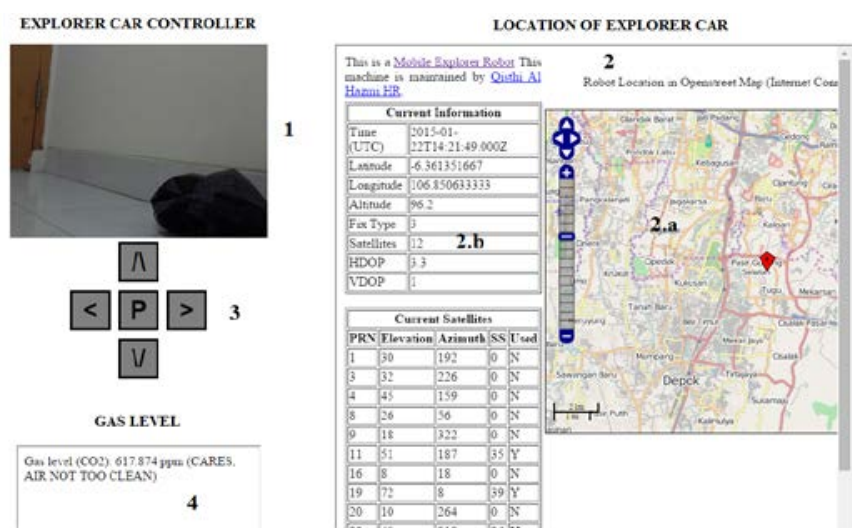

Gambar 14. Halaman Utama Antarmuka Web Mobil Penjelajah

Berikut ini adalah flowchart dari fungsi daripada antarmuka web untuk sistem kendali juga monitor mobil penjelajah pada penulisan ini. 

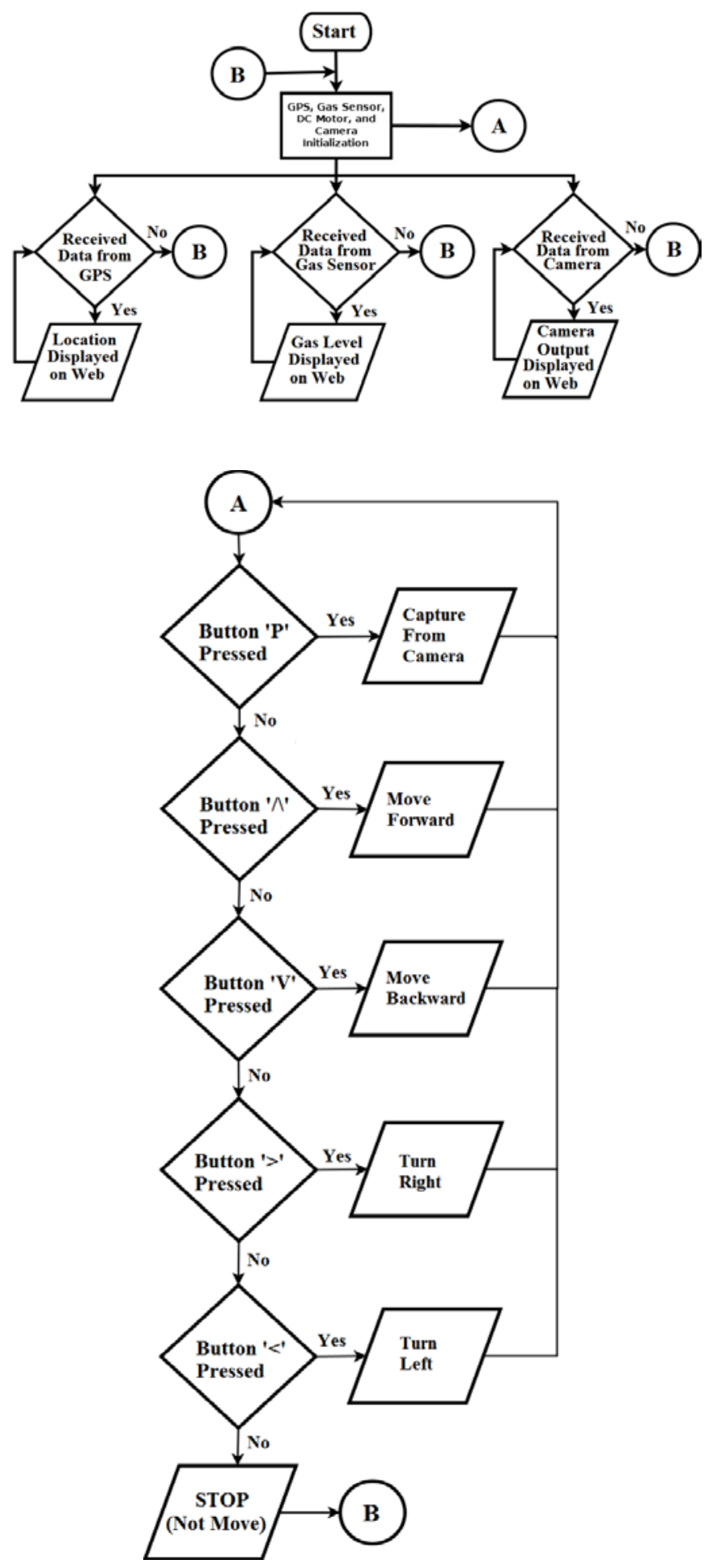

Gambar 15. Flowchart Program Sistem

\section{G. Ujicoba Jarak Kendali}

Pengujian jarak kendali digunakan untuk mengetahui jarak maksimal yang dapat diterima oleh pengguna terhadap robot penjelajah. Kondisi yang diambil berdasarkan kualitas sinyal ( 0 - 5 bar) yang diterima oleh laptop pengguna. Pada penulisan ini dilakukan dua kasus pengujian, yaitu kasus dalam ruangan dan kasus luar ruangan.

Untuk pengujian pertama, yaitu pengujian di dalam ruangan. Mobil penjelajah dihadapkan dengan 3 tembok sebagai penghalang komunikasi. Hasil ujicoba pada pengujian di dalam ruangan adalah sesuai pada tabel 3 berikut:

Tabel 3. Ujicoba Jarak Kendali Mobil Penjelajah Kasus Dalam Ruangan

\begin{tabular}{cccc} 
Ujicoba & $\begin{array}{c}\text { Jarak dari user } \\
(\mathbf{m})\end{array}$ & $\begin{array}{c}\text { Penghalang } \\
\text { (tembok) }\end{array}$ & $\begin{array}{c}\text { Kualitas } \\
\text { Sinyal } \\
\text { (bar) }\end{array}$ \\
\hline $\mathbf{1}$ & $<1$ & 0 & 5 \\
\hline $\mathbf{2}$ & $1-3$ & 1 & $5-4$ \\
\hline $\mathbf{3}$ & $3-6$ & 1 & $4-3$ \\
\hline $\mathbf{4}$ & $6-9$ & 1 & $3-2$ \\
\hline $\mathbf{5}$ & $9-13$ & 2 & $2-1$ \\
\hline $\mathbf{6}$ & $13-17$ & 2 & $2-1$ \\
\hline $\mathbf{7}$ & $17-20$ & 3 & $1-0$ \\
\hline $\mathbf{8}$ & $>20$ & 3 & 0 (mati) \\
\hline
\end{tabular}

Untuk pengujian kedua, yaitu pengujian di luar ruangan. Pada pengujian di luar ruangan, mobil penjelajah melaksanakan pergerakan bebas tanpa adanya halangan baik tembok maupun pohon. Hasil ujicoba pada pengujian di luar ruangan adalah sesuai pada tabel 4 berikut:

Tabel 4. Ujicoba Jarak Kendali Mobil Penjelajah Kasus Luar

\begin{tabular}{ccc} 
Ujicoba & $\begin{array}{c}\text { Jarak dari user } \\
(\mathbf{m})\end{array}$ & $\begin{array}{c}\text { Kualitas Sinyal } \\
\text { (bar) }\end{array}$ \\
\hline $\mathbf{1}$ & $1-6$ & 5 \\
\hline $\mathbf{2}$ & $6-12$ & $4-5$ \\
\hline $\mathbf{3}$ & $12-18$ & $4-5$ \\
\hline $\mathbf{4}$ & $18-24$ & $4-5$ \\
\hline $\mathbf{5}$ & $24-30$ & $3-5$ \\
\hline $\mathbf{6}$ & $30-36$ & $3-4$ \\
\hline $\mathbf{7}$ & $36-42$ & $3-4$ \\
\hline $\mathbf{8}$ & $42-48$ & $2-4$ \\
\hline $\mathbf{9}$ & $48-54$ & $2-3$ \\
\hline $\mathbf{1 0}$ & $54-60$ & $1-2$ \\
\hline $\mathbf{1 1}$ & 60 & $0-1$ \\
\hline $\mathbf{1 2}$ & $>60$ & $0(\mathrm{mati})$ \\
\hline
\end{tabular}

\section{KESIMPULAN}

Berdasarkan dari hasil perancangan dan uji coba, dapat disimpulkan bahwa perancangan mobil penjelajah dengan sistem kendali jarak jauh melalui jaringan Wi-Fi dengan pengantarmukaan website dapat berjalan dan berfungsi dengan baik pada jarak tertentu, yakni 55 hingga 60 meter di ruangan terbuka dan 15 hingga 20 meter di ruangan tertutup dengan beberapa kondisi jumlah pembatas tembok yang bervariasi. Implementasi sensor gas dan sensor GPS pada mobil penjelajah dapat berfungsi dengan baik, sehingga hasil keluaran sensor gas, yang mana merupakan konsentrasi 
karbondioksida (dalam ppm), dan lokasi yang diberikan oleh sensor GPS, berupa longitude dan latitude dapat ditampilkan dengan baik pada antarmuka web. Untuk tampilan peta lokasi (OpenStreetMap) pada web yang diberikan oleh sensor GPS dapat ditampilkan apabila pengguna terhubung dengan jaringan internet.

\section{REFERENSI}

[1] Braunl, T. (2008). Embedded Robotics: Mobile Robot Design and Application with Embedded System $2^{\text {nd }}$ Edition. Berlin: Springer.

[2] Hidayat, D. B. (2013). Control System Mobile Telerobotic with Web-based Interface. Jakarta: Universitas Gunadarma.

[3] Richardson, M. dan Wallace, S. P. (2012). Getting Started with Raspberry Pi. Sebastopol, CA: O’Reilly Media.

[4] U.S. Government Information about The Global Positioning System. (2015). GPS.gov: GPS Overview.
Diakses dari https://www.gps.gov/systems/gps/ pada tanggal 31 Mei 2018.

[5] Chowdhury, M. N., Nooman, M. S., dan Sarker, S. (2013). Access Control of Door and Home Security by Raspberry Pi through Internet. International Journal of Scientific and Engineering Research, 4(11), 550-558.

[6] Minch, E. (2014). Raspberry Pi, Python, Digital Cameras, and Speed Detection: Lessons Learned. American Society for Engineering Education Southeast Section Conference.

[7] Rezki, N., Yusfi, M., dan Yendri, D. (2013). Rancang Bangun Prototipe Pengurang Bahaya Gas Polutan dalam Ruangan dengan Metode Elektrolisis Berbasis Mikrokontroler. Padang: Universitas Andalas.

[8] Kane. (2015). What are safe levels of CO and CO2 in rooms?. Diakses dari http://www.kane.co.uk/knowledgecentre/what-are-safe-levels-of-co-and-co2-in-rooms pada tanggal 31 Mei 2018. 